\title{
The Influence of Prenatal, Home and Environmental factors on Learning Outcomes of Pre-Primary School Children
}

\author{
Dr (Mrs.) Elizabeth Ebun Abolarin \\ Department of educational psychology/ guidance and counsellingFct, coe zuba
}

\begin{abstract}
The positive influence of early childhood education on school readiness and the rise in maternal employment have made pre-primary education a norm in many nations, Nigeria inclusive. Most children of 2 to 5 years, especially of working mothers, attend a regulated early education service in Nigeria (Abolarin, 2014). Pre-school services play an important role in child development by giving children an opportunity to engage in a range of educational and social activities. Moreover, pre-school education could have positive influences in children's affective, conceptual and social development in subsequent years (Gormley, Gaver, Phillips \& Dawson, 2005). Inspite of these positive influences, various emotional, adjustment and academic problems are noticed in pre-school pupils (Tombowa, 2013). To realize the benefits of pre-school education, this paper discusses the influence of prenatal, home and environmental factors on learning outcomes of pre-school children. Major recommendations made include the need for government to strengthen intensive care services of expectant mothers and the quality control structures of pre-school education to maintain very high standards.
\end{abstract}

\section{Introduction}

The Nigerian government considers pre-primary education as being critical for a smooth transition from the home to the school and for preparing the child for adjustment and successful learning in higher level of education. Efforts are being made to ensure that the main method of teaching is through play, having childfriendly school environments and that the teacher to pupil ratio does not exceed 1:25 per class (Amakievi, 2013). Because pre-school education is mainly provided by non-governmental organizations and private individuals, the Federal Government of Nigeria (FGN) reviewed and emphasized the educational law relating to the establishment of pre-primary schools and also put in place_regular inspection by officials of the Ministry of Education for maintenance of high standard. This is to ensure that pre-primary schools are well administered with qualified teachers and provision of necessary infrastructure (Maduewesi, 2005a). Since pre-school educational services equally provide care and supervision for children while career mothers are at work the scheme has been readily accepted by majority of them. In the study carried out by Abolarin (2014) on how employed mothers fulfill their marital roles expectations, all 250 employed mothers in the study indicated they usually send their children to either nursery or pre-primary schools. Her finding demonstrated how career mothers value pre-school education. Thus, as more women become employed in both formal and informal sectors of the economy, the need for primary schools increased. Maduewesi (2005a) reiterated that the expansion of pre-primary schools was necessitated by the changing phase of economic life. Unfortunately, it has been observed that more and more working mothers tend to rely extensively on early educational care services to the extent of down-playing their own parental guidance and control (Abolarin, 2014). Some pre-school age children stay in school for 9 hours per day $(7.30 \mathrm{am}-4.30 \mathrm{pm})$. The long hour of stay could make them to imbibe unwholesome habits from their peers which could be detrimental to their adjustment to parental values and discipline (Hickman, 2006). Non-maternal care, the amount of time spent in kindergarten and inadequate supervision for quality standard were associated with an increased likelihood of behavioural and socioemotional problems, as well as poor responses to learning by pre-school children (Okorodudu, 1995; Marcon, 2002). From the foregoing, it is evident that the government manifests great concern for the learning development of pre-school children and parents too rely heavily on pre-school educational services. The risk to physical and emotional health of children due to inadequate care and supervision in some pre-primary schools are observed and reported (Tambowa, 2013; Okoro, 2004). It therefore becomes necessary to examine the factors that could influence pupils at the pre-school levels for their proper adjustment to school, promotion of healthy emotions in them as well as positive learning outcomes. The categories of the factors considered include: pre-natal, home and environmental factors.

\section{The Preschool Age Child And Pre-Primary Education}

In relation to Nigerian educational system, the pre-school age child is from 3 to 5 years. At this age children display great curiosity about the happenings and objects around them, even as they engage in a variety of activities such as: undertaking and solving challenging tasks, learning basic skills through direct play and various social interactions, and playing games with their peers (Abolarin, 2010). The developmental task of this 
period is to develop active and purposeful behaviours, to be able to cope with using their initiatives in doing some things on their own. If they are allowed to explore their environment and are rewarded for their effort and their numerous questions are answered they will develop a sense of initiative and become confident of their ability to make decisions. But if they are discouraged either through criticism or undue restrictions, they will develop a sense of guilt over self initiated activities and suppress their curiosity (Erikson, 1968). Erickson's theory on the psycho-social development of the child provides a key understanding on how to adapt any educational service delivery to develop high self esteem, decision making and relationship skills in the preschoolers.

Pre-primary education is the education given in an educational institution to children from age 3-5 years who are yet to attain the school-going age. It is a part of early childhood education (FRN, 2004). The focus is on developing in children background skills and knowledge that will prepare them for primary school education prior to their entering primary school (FRN, 1998). As it relates to pre-primary programme, formal education is defined as a process whereby some qualified, experienced and parent-like teachers direct and guide the growth and development of school pupils towards achieving basic learning skills for success in life (Ojameruaye, 2010). Pre-primary education emphasizes availability of the right type of environment for the individual child to develop physically, intellectually, socially, emotionally, and morally. This will enable him to develop harmoniously within himself and together with other people in his surroundings. The curriculum of a typical pre-primary school focuses on the teaching of English language through recognition of letters of the alphabets, pronunciation of words, construction of simple sentences, recognition of numbers, counting and simple addition of numbers, identification of shapes and colours of objects, drawing and painting, writing, reading, rhymes' recitation, story-telling etc (Barnett, 2006). The factors that contribute to effective learning outcome of preschool age children are many, only a few of them are presently discussed.

\section{Effect Of Prenatal Factors On Learning Outcome Of Preschool Children}

The prenatal stage of child development is from conception to birth. The health condition of the mother during pregnancy, her emotional state, feeding habit, drug usage and environment of living are pre-natal factors that could affect the health, mental and physical development of the child including his/her academic performance after birth (lannucci, 2000). For example, poor feeding can cause mental retardation, just as sexually transmitted diseases (STDs) like syphilis, gonorrhea in the mother have been reported to cause damage to the developing organs and bones of the unborn child. Likewise, alcohol consumption, cigarette smoking and use of cocaine by expectant mothers can be devastating to the unborn children (Olson, 2000). As observed by Hallahan, Kauffman \& Lloyd (1999), the effects of this prenatal hazard on the developing child are enormous. Children who are affected by these problems are usually weak, sickly, retarded and at times, prone to physical challenges and learning disabilities. Olson (2000) further discovered that pregnant women who subjected themselves to heavy intake of alcohol, gave birth to children who suffered from Fetal Alcohol Syndrome (FAS), which is a cluster of abnormalities that include mental retardation, facial deformities, defective limbs and hearts. Studies revealed that most of these children are below average in intelligence, and are usually less attentive and alert while studying (Gray, Davis, McCoy, Dean \& Joy, 1992; Olson \& Burgess, 1996).

Abolarin \& Okeke (2009), discovered that poor health and nutrition in the early years undermine children's chances of attending school. They observed that nutritional supports through feeding programmes in schools greatly improved children enrolment, attendance in school and their general academic performance. It was also suggested that a life-cycle approach be effected beginning with maternal child health programmes as well as the integrated management of childhood illnesses during infancy. They also advocated continuous family support through Early Childhood Care Education (ECCE) programmes to ensure that children will be able to enroll in primary school and benefit from the growing number of school health programmes. Minet (2000) equally discovered that weight gained in the first two years of life is an important predictor of schooling outcomes. He opined that it was not weight gain per se that contributed to cognitive development, but rather that growth failure in early childhood due to the lack of nutrients at the cellular level which has systematic effects on growth and development in general, and also in brain development in particular. He stressed that the provision of nutritional supports for pregnant mothers and very young children is a critical component in achieving educational goals at preschool age.

\section{Effect Of Home Factors On Learning Outcomes Of Preschool Children}

The factors that are considered to be home factors which could influence pupils' learning outcomes at the preschool level of education are: the family/marital status, parental level of education, parents economic strength, involvement in the child's academics as well as inherited traits. We shall discuss each factor one by one. 


\section{a) Parents Marital Status And Children's Learning}

Marital status refers to the state of parents being together as a husband and wife or being widowed, separated, divorced or never married. This state has positive and negative effects on pupils' performance at school, depending on the organization of each family member. Shekwoyandu (2014) confirmed that there is a link between parents' marital status and pupils' learning outcomes. He observed that a polygamous home and extended families having low income will influence pupils academic performance badly because many children over burden the parents, who are unable to cope with supporting their children's education adequately. In homes where parents quarrel often, the children are neglected; hence, they perform poorly in school. Lack of cordial understanding in a family causes instability and inability to control children's behaviours which in turn may lead to such children performing poorly in school. Similarly, divorced parents exercise less control over their children and the negative impact is most noticeable on the preschool children, because they tend to be emotionally unstable. Reynold, Maverogenes, Bezruczko \& Hagemann (1996), pointed out that marriage is a bond that introduces two families to another and unites them and even the clans. Once the full contact of marriage is broken, it creates a great scar in the families concerned and has traumatic effects on the behaviours and academic performance of their children. They found that parents' marital status actually has significant effects on pupils' academic performance. They emphasized that children living with their step-mothers are targets of mis-directed emotions and mis-treatments, while those from stable families tend to perform far better in school. They also linked the separation of parents as a destructive event in a family, to children's performance in all aspects of life. Reynolds et al, noted that children from single-parent families receive less adult attention, affection, love, sympathy, guidance and security and consequently, are often emotionally disturbed and show lack of concentration in class. Parents should resolve their marital conflicts by discussing their differences accommodate each other and if necessary, seek the intervention of a mediator such as a counsellor to restore peace in their home. This will help to maintain the peace of the family, the health and learning success of their children (Adamu, 2002).

\section{b) Level Of Education Of Parents And Children Learning Outcome}

Level of education of parents is the degree to which parents have acquired some knowledge, skills, attitudes and values of informal and formal education. Reynold et al., (1996) revealed that parents' level of education is very crucial for the performance of their children. This is because most educated parents appreciate more the need to provide adequate learning materials for their children, which can stimulate them to learn and perform better in school. Such parents are usually concerned with their children's performance, and are inclined to create time to coach their children or appoint part-time teachers for them. Many send their children to the best nursery and primary schools available which serve as sure gateways to secondary and university education. This in turn leads to Higher Educational Qualifications which often serves as a spring board to higher positions in the society. Preschoolers need parental supervision with respect to their adjustment behaviours and learning outcomes. Parents with high academic qualifications are in better position to render adequate help to their children academically (Durojaiye, 1999).

\section{c) Level Of Family Income}

Family income is the state at which a family receives money regularly, over a reliable period of time through payment for work or returns on investments. Behrman (1997) affirmed that family income has great influence on the educational opportunities available to children and on their chances of educational success. In Nigeria today, preschool education is provided for profit majorly by private individuals. The cost of standard pre-primary education is generally high and cannot be afforded by poor families that could hardly satisfy the basic needs of their children for food (balanced diet), clothing, convenient and secure accommodation, good water supply and recreation. High fee-paying schools are patronized by the rich and such schools provide better quality education in terms of curriculum delivery, qualified staff, learning facilities and a conducive learning environment. Thus, children of low socio-economic parents attend substandard schools (Ejieh, 2006). Children from poor home background often suffer serious diseases due to malnutrition and poor standard of living that leads to their poor performance at school. Behrman observed that children of rich parents have far better opportunities of getting into better nursery schools than equally bright children of poor parents and affirmed that low achievement is closely related to lack of resources. In a study carried out in Zambia, East Africa, Sherman \& Ellen (2007) suggested the need to develop a Nutrition and Health Education Programme with inclusion of school meals to cater for the health of children of poor families in order to attract them to school. This initiative was equally supported by Abolarin et al. (2009), who discovered that the implementation of School Feeding Policy into the Universal Basic Education (UBE) Programme in Nigeria resulted in a remarkable improvement in the enrolment, attendance, retention and completion, comprehension and learning achievement of school children. 


\section{d) Influence Of Parents' Involvement And Pupils' Performance}

The involvement of parents on a child's development determines the future of the child. With respect to the child's performance, parents' involvement in the child implies being readily available for the child, helping in take-home assignments, making contact with the teachers, attending school functions, ensuring the child's punctuality to school, keeping him/her neat and healthy, etc. (Baydar, Greek \& Gritz,1999). When there is cooperation between the school and families to support learning, the children tend to succeed academically and throughout life. The most accurate prediction of a pupil's academic achievement in the pre-primary stage is not based on parental income or social status, but rather on the extent to which the parents interact with the child to create a home environment that encourages learning and also express high expectations in the child's potential to achieve (Minet, 2000). The health of the child should be promoted by ensuring an environment that is safe and free from physical, sexual and emotional abuse or injury. Parents need to provide the child with basic needs, such as water, nutritious food, shelter, medical care when ill and clothing that is appropriate for the weather conditions. Parents should assist in promoting the child self-esteem needs by accepting and respecting his or her uniqueness or individuality and setting expectations that are realistic (O'Connor \& Scott, 2007). The child should be taught essential relationship skills and moral lessons. Parent should not criticize or ridicule the child rather he should be corrected when wrong, appreciated when right and be trained to exhibit pleasant emotions. Parents who are able to show their involvement in the life of their children in all such possible ways often have children that are well adjusted to school life and consequently perform better in preschool education.

\section{e) Hereditary factors}

Inherited traits determine children's intelligence, physical appearance and equally contribute to their personality and temperament. Children of intelligent parents are most likely to be intelligent. Hence, the child should be allowed to learn at his/her own pace without making comparison with other age mates. High intelligence forms a good basis for knowledge which makes understanding, assimilation and remembering of learning materials to be easy (Abolarin, 2010). A child who is barely average intellectually may be slow in acquisition of knowledge and ability to recall what is learnt. Intelligence also manifests in the area of giftedness, such as numerical ability, language processing, visual processing and psychomotor activities. For example, preschool children who are talented in verbal aptitude might show quick and better memories for words and pronounce words better than those who are gifted in numerical ability. Children having numerical strength are likely to recall a list of numbers faster and accurately. Those gifted in visual processing will be very good in colour identification, while a talented child in limbs or psychomotor coordination will tend to draw, paint and write better, easier and faster (Hallahan \& Kauffman. 2003). Parents and teachers need to pay closer attention to the areas of strength of each child for proper development and improvement in the weak areas.

Another characteristic which is largely determined by hereditary factor and could have impact on the academic performance of children at this age is the temperament. Abolarin (2010) defined temperament as the innate disposition that reflects the characteristics of a child, manifesting in matters such as interests, approach to issues and the control of feelings or emotions while reacting to situations. Preschool children show interest in different things and they react in various degrees to the same thing at other times. Some may show deep interest in drawing and painting, another group may be interested in story-telling, some in fixing legos, some in rhyme recitation. A child's interest in a learning activity affects his or her performance in that class activity. Moreover, preschool children react to frustrations in different ways. For example, the first day in school, a preschool child may cry for quite a while being in the midst of strangers with unfamiliar faces. Another child may cry for the same frustration for a much longer duration before accepting the new situation. The intensity of responses to favourable and unfavourable situations differ because it is determined largely by the child's temperament. The teacher also as a care-giver could equally help pupils to manage their emotions by rewarding children who exhibit pleasant emotion and by discouraging unpleasant ones. Teacher should also create a friendly atmosphere that is both conducive and interesting to the pupils (Mitchell, 1990).

\section{Effects Of Environmental Factors On Learning Outcomes Of Preschool Children}

The environment of learning is a very critical factor for preschool children that can significantly impact on their learning outcomes. The following are categorized as environmental factors: the condition of the school in terms of location, available facilities and equipments, class size, teacher quality and methods of teaching, instructional materials, peer relationship and school mobility. Some of these points are discussed below:-

\section{A. School Location}

The site of a school often affects pupils' academic performance. Ideally, a school should not be sited near a market, a garage, a river, a canal, a filling station, an airport, under electric cables, on a high way, near a factory, a hotel, music and cinema houses or a zoo. The topography of the school is equally important as this should not be on a hill or in a ditch. The landscaping of the school with good drainage is of much importance as 
well. If a school is close to a river or a canal it could hardly be free from invasion by dangerous reptiles. Fire accident could occur in filling station or violence in a hotel, a cinema house or a Motor Park. Also schools that are located in an unkempt waste disposal environment may be infested with rats with the attendant dangers that the rats' faeces can contaminate children toys. All these create fear in innocent pupils who cannot help themselves and are threats to learning (Moore, 1998). Also, external noise level either from air-traffic noise, sound of machines in factories or blaring of music from public entertainers are causes of discomfort to learners and teachers alike and could impair learning (Cash, 1993; Lackney, 1994).

In Nigeria, until recently, the expansion of preschool education facilities took place mainly in urban and semi-urban area of the country. Ejieh (2006) observed that very few pre-primary schools were sited in rural areas because of lack of markets for proprietors while the few that existed in the rural areas were likely to be unregistered and that their services were sub-standard in terms of facilities, equipments, and quality of teachers. Such rural preprimary schools usually make their charges relatively low in the effort to make their services affordable to interested parents. However, the educational gap between the rural and urban settlement became reduced through the initiative on early child care undertaken by the United Nations Children's Education Fund (UNICEF) in collaboration with Nigeria's Federal and State Governments. This initiative has led to the establishment of 2,045 community-based and low cost early child care facilities in rural and poor urban areas for 75,000 children in 10 selected states in Nigeria (Okoro 2004). In this vein, equal opportunity to standard preprimary education is advocated for pre-school age children in rural areas of the nation.

\section{B. School Facilities, Equipment And Personnel}

Many pre-school children could hardly complain of inconveniences in schools. Discomfort often manifests in their ill-health. As such, very fascinating facilities is a main attraction to preschoolers and their parents. The environment of learning should be conducive, beautiful, orderly, clean and natural. The class-room should be spacious with moderate humidity level and temperature to prevent air-borne bacteria, and mould or fungi infections which could cause asthma or body rash in children. Schools need good and adequate ventilation because children breath a greater volume of air in proportion to their body weight than adults. Children in a classroom that lack adequate ventilation cannot function normally and cannot learn at their capacity (Hine, 1996). The furniture should be age-appropriate and arranged in a way that will ease movement in the classroom. Classroom lighting plays a critical role in pupils' academic performance. Obviously, children cannot learn unless lighting is adequate. According to Benya (2001) appropriate lighting catches pupils' attention, gets them excited, reduces off-tasks behaviours and plays significant roles in children's achievement. For example, with adequate lighting, children perform better in colour identification. The toilet facilities should be adequate and convenient for pupils with separate toilets rooms for males and females. Pre-school children drink much water because of their involvement in physical exercises and play. The toilet facilities should be convenient for them to let out the body waste products either through urinating or defecating. Availability of pipe-borne water or bore-hole water is highly essential.

There should be very good, manicured lawns and close-to-nature playing ground in a secure place provided with the necessary playing gadgets and close supervision when in use. First-Aid Box and a School Clinic that is well equipped with necessary drugs and qualified, certified and experienced medical personnel on full time shold be put in place. Provision of the school buses is also essential to ensure easy movement when necessary. Among the needed facilities for pre-school children are a dining section where they could have their meals during break, and a convenient room with bedding facilities for resting or sleeping. The school should be fenced and the gate manned by security men who are alert at work (Jago \& Tanner, 1999). The availability of appropriate facilities promotes learning and enhances pupils' performance. More importantly however, the environment of learning should be made beautiful, as natural as may be possible, orderly and clean.

\section{Class Size}

A well designed and implemented class size reduction programme at the pre-primary level often leads to a rise in pupils' academic achievement. A class size of 18 pupils maximum per teacher is required to produce the greatest benefit. Reducing class size will have little effect without enough classrooms, well qualified teachers, professional development programmes for teachers and a detailed curriculum. All these will enhance the effects of reduced class size on pupils' academic achievement. The class size varies widely in Nigeria depending upon the school location, the proprietorship, type and quality of facilities, teaching staff, and official policy (Ejieh, 2006) but the standard approved class size is a maximum of 25 pupils in a class (FRN, 2004, p12). Some schools however, have set a teacher-pupil ratio of: 1 to 20; 1 to 25; 1 to 30; or higher. The more congested the class, the more difficult it will be for pre-school pupils to learn (Evertson \& Harris, 1992). 


\section{Quality Of School Personnel}

There should be essential personnel on hand for pupils' well-being and learning. Such personnel will include professionally experienced and committed Head teacher, qualified teachers possessing relevant training and knowledge of early child care education (ECCE), at least two helpers per class, a school counselor, caterers, cleaners, and gardeners, etc.

The maintenance of a healthy child-friendly environment managed by well qualified university graduate teachers often necessitates high charges (Rolnick \& Grunewald, 2003). The effect of high fees is particularly negatively strong among pupils from low-income families who tend to rely solely on teachers' effort since their parents might not be financially strong enough to employ the assistance of home instructors. Rolnick et.al., (2003) opined that parents willingness to cope with high fees will enable them to give their children functional foundational education. In an earlier study by Birch \& Ladd (1996), they had discovered that pupils' academic performance is more heavily influenced by teacher quality far more than by pupils' class-size or the type of school they attend. Therefore, teachers of preschool pupils should preferably, be graduates of Early Childhood Care and Education (ECCE) or Primary Education Studies (PES), who possess an appreciable knowledge of child development, micro-Teaching and Classroom management.

The benefits associated with being taught by good teachers are cumulative. The achievement gap widens progressively between pupils with most effective teachers and those with least effective teachers. This suggests that the most significant gains in academic achievement will likely be realized when pupils receive instruction from good teachers over consecutive years. A good teacher must ensure the establishment of the following criteria to maintain and guarantee the child's academic success.

i. The lesson should enumerate steps towards practicing what is taught.

ii. Provision of an orderly model of working for the child to imitate.

iii. The development of independence through practice.

iv. Freedom from interference when practicing.

v. Specification of incentive for individual efforts.

vi. Provision of feedback to parents and wards on pupils' performance.

vii. Opportunities for pupils to experience self-esteem and gain self-confidence.

\section{E. Method Of Teaching}

The most effective method of teaching pre-primary children is play method originated by Maria Montessori. It is an active method of teaching that is child centered and based on child development theories. Montessori propounded that the development of a child is in stages and that at every stage, the child engages in a particular form of play through which he/she acquires learning (Efuniyi, 1999). With respect to the learning of preschoolers, play is doing educative things that they equally enjoy, either together with others or alone and with or without the use of tools like toys. The child, the teacher and the environment are the three interdependent and functional components, that operate together to bring about effective learning through play and the child is the focal point. The goal of teaching is to inculcate social norms and to ensure the development of the child's intelligence as well as physical and physiological abilities within a carefully prepared environment which exposes the child to age appropriate learning materials and experiences (Abolarin, 2011).

\section{F. Instructional Materials}

For learning to be effective and interesting in the preschool programme, the teachers must use different types of toys as play materials. Toys are physical and man-made items used as tools of play for children, thereby providing them fun and amusement. Educational toys are toys that challenge, stimulate or encourage children to learn through play (Obadiah, 2008). It is necessary to emphasize that improvisation and display are central to the use of toys in teaching and learning. This is because the preschool child learns through experimentation, discovery, visual process and playing with objects. Toys help their cognitive growth and the development of fine motor skills; can improve attention span and problem-solving ability. Toys are in various forms and meant for different age groups. For effective learning, teachers should use toys that are age appropriate and relevant to the topics (Chiaka, 2008). Moreover, the child should be able to use the toys easily without adult assistance, and toys should be things that are related to the child's environment, community or world. The toy should be safe (not having sharp edge) durable, beautiful, re-usable and affordable. Their use should help the child to develop positive social interactions through free expression of his/her emotions or concern for others (Hua \& Lohya, 2006). Teachers must be conversant with how to use toys and what learning is to be imparted in the learners from the use of each toy should be specified. The use of toys should be for instruction and the development of skills and not just for recreational purposes. When the ready-made toys are not available or too expensive, the teacher should use his/her creative ability to improvise the needed toys from available materials. 


\section{G. Peer Relationship}

During the pre-primary years, peers relationship plays important roles in children's social and cognitive development which has great influence on the learning experiences of the individual child (Andreas \& Pischke, 2006). Peer play allows children to interact with others whose level of development is similar to their own. Because children imitate themselves, they cooperate and pay attention to academic work better while in the midst of their peers than when alone (Burke., \& Sass, 2011). From their relationship with peers, children learn how to follow directions, how to take turns, stick to a task for a specific period, cooperate with others in a joint work and how to resolve conflicts. They also display good manners, such as table manners, sympathy, courtesy, sharing, turn-taking etc.

\section{H. Frequent School Mobility}

Demie (2002) discovered that children who frequently change schools have problems of poor adjustment to learning and often perform poorly. Frequent school mobility could be associated with parental change of residence, and since preschoolers cannot go to school on their own, parents seek for ease of 'school run' which will necessitate transferring children to nearby schools. Other factors are low income status, singleparent households, and stressful life events such as divorce, death of a spouse or remarriage in the family. In some cases, children are required to change schools due to grade repetition and behavioural difficulties in one school or for reasons that are related to any unexpected changes in the pattern of the school system. For example, if a school does not service the next grade (which is common in pre-primary classes) or an entire school closes down, then all children must change schools. Other reasons for a change in a child's school could be that he or she may attend a better school as a result of the transfer of parents to a place that has offered better jobs. Irrespective of the reasons for change, studies suggest that frequent change of schools, impact negatively on the general academic achievement as well as oveall progress of a child (Franke \& Hartman, 2003). This is because some children may find it difficult to easily form new friends, adjust to different styles of teaching or the faces of new class helpers. As much as possible, parents should endeavour to restrict frequent changes in their residential accommodation or work location in order to promote the adjustment of their pre-school children to school and learning.

\section{Recommendations}

1. To enable pre-school age children in Nigeria acquire maximum benefits from the lofty objectives of preprimary education policy, there is the need for the implementation of the following recommendations.

2. The Federal, State and Local Governments should assist in the provision of infrastructural facilities for preprimary education.

3. The effort by Government, assisted by the UNICEF for intensive health care of expectant mothers should be re-invigorated.

4. There is the need for greater collaboration between the State Ministries of Education (SMEs) and the Federal Ministry of Education (FME) with the former ensuring the adherence to stipulated regulations by the providers of pre-primary education.

5. The inspectorate division of the State Ministry of Education (SME) should enforce control through effective monitoring and thereby ensure that minimum standards are maintained. Providers of pre-school educational services that ail to meet the minimum standards should be sanctioned.

6. The Federal Government should intensify training for teachers who specialize in early childhood education to teach in pre-primary schools

7. Government should regulate the cost of pre-primary education to minimize undue exploitation by profitdriven proprietors and proprietress of schools.

\section{Conclusion}

The learning outcomes of preschoolers appear to be influenced by a variety of factors. These include: the child's state of health both at prenatal stage and after birth, his or her intelligence, and temperament, interaction with parents and peers, parental socio-economic status, a very conducive environment of learning, teacher quality, appropriate teaching method and teaching materials. All stakeholders in education should endeavour to ascertain that all these factors are promoted and improved upon for positive effects on the academic achievements of preschool children.

\section{References}

[1]. Abolarin, E.E. (2010). Essentials of developmental psychology: A foundation for teaching.

[2]. Abuja: Petra Digital Press.

[3]. Abolarin, E.E. (2011). Play method/role Play: In teaching and learning process. Nigerian Journal of Educational Productivity and Contemporary Issues, 5(2), 23-37.

[4]. Abolarin, E.E. (2012). Classroom management and discipline in primary schools. Nigerian Journal of Educational Issues, 3(2), 1-7. 
[5]. Abolarin, E.E. (2014). Fufilment of marital role expectations as perceived by employed mothers in FCT Abuja: Implications for Marital counselling. International Journal of Science and research, 3(11), 2852-2859.

[6]. Abolarin, E.E., \& Okeke, U.J. (2009). Public rating of the home-grown school feeding policy of the Universal Basic Education Programme. Affrican Journal of Allied Education, 3(1),115 - 126

[7]. AmaKievi, O.I.G. (2013). Historical analysis of federal government innovations in early childhood education in Nigeria, 1977 2008. International journal of Academic Research in Business and Social Sciences, 3(1), $63-84$.

[8]. Andreas, A., \& Pischke, S. (2006). Peer effects in European primary schools: Evidence from PIRLS, London: School of Economics.

[9]. Barnett, W.S. (2006). Research on benefits of Pre-school education: Securing high returns from pre-school for all children. NewYork: National Institute for Early Education Rsearch.

[10]. Baydar, N., Greek, A., \& Gritz Mark, R. (1999). Young mothers time spent at work and time spent caring for children. Journal of Family and Economics Issues, 20(1), $61-84$

[11]. Behrman, R.E (1997). Children and Poverty. The future of children, 7(2), 154-160.

[12]. Benya, J.R. (2001). Lighting for Schools. Washinton D.C: National Cleaning House for Educational Facilities.

[13]. Birch, S. H., \& Ladd, G. W. (1996). Continuity and change in the quality of teacher-Child Relationships: links with children's early school adjustment. Child development, 67 (1), $980-1012$

[14]. Burke, M. A., \& Sass, T. R. (2011). "Classroom peer effects and student achievement" Boston: Federal Reserve Bank Cash, C.S. (1993). A Study of the relationship between school building conditions and student achievement and behavior. Blacksburg, Va: Virgina Polytechnic Institute and State University.

[15]. Chiaka, P.D (2008). The use of instructional materials for sound academic delivery in Nigeria. The FCT Education Secretariat Journal of Curriculum Studies and Instruction (1), 107-112.

[16]. Durojaiye, J. (1999), Manual of Child Guidance. USA: Edwards Brother Incorporation.

[17]. Efuniyi, B. (1999). Fundamentals of Montessori method of education. Lagos: Centre For Montessori Education.

[18]. Ejieh, M.U.C. (2006). Pre-primary education in Nigeria: Policy, Implementations and Problems. Elementary Education Online, 5(1), 58-64.

[19]. Erikson, E.H. (1968). Identity Youth and Crisis. In E.E. Abolarin, Essentials of developmental psychology: A foundation for teaching.Abuja: Petra Digital Press.

[20]. Everston, C.M., \& Harris, A. H. (1992). What we know about managing classrooms. Education Leadership, 49 (7), $49-58$

[21]. Federal Ministry of Education, (2013). State of Edcation in Nigeria below tertiary level.

[22]. Abuja: Federal Inspectorate Service.

[23]. Federal Republic of Nigeria (1998) National Policy on Education (3rd edn). Lagos: NERDC Press.

[24]. Federal Republic of Nigeria (2004) National Policy on Education (4th edn). Lagos: NERDC Press.

[25]. Gormley, W.T., Ted, G., Phillips, D., \& Dawson, B. (2005). The effects of universal Pre-K cognitive development. Developmental Psychology, 41(6), 872-884.

[26]. Gray, J.W., Davis, B., McCoy, K., Dean, R.S., \& Joy, K.L. (1992). Mothers' self reports of prenatal information as predictors of school achievement. Journal of School of Psychology, 30, 233-243h

[27]. Hallahan, D.P., \& Kauffman, J.M. (2003). Exceptional learners: Introduction to special education ( $9^{\text {th }}$ edn). Boston: Allyn and Bacon.

[28]. Hallahan, D.P., Kauffman, J.M., \& Lloyd,J.W. (1999). Introduction to learning disabilities ( ${ }^{\text {th }}$ ed). Boston: Allyn \& Bacon.

[29]. Hickman, L.N. (2006). Who should care for our children? Journal of Family Issues, 27(5), 652-684.

[30]. Hines, E. W. (1996). Building condition and student achievement and behaviour. Virginia: D. Ed. Diss.

[31]. Hua, R.,\&Lohya, I. (2006). Training of caregivers on the production of toys and stimulating materials. A workshop paper for Basic Education Board (UBED), FCT Abuja-Nigeria.

[32]. Iannucci, I. (2000). Birth defects. York: Enslow.

[33]. Jago, E., \& Tanner, K. (1999). Influence of the school facility on student achievement. Athens; Department of Education Leadership University of Georgia

[34]. Lackney, J. A. (1994). Educational facilities: The impact and role of the physical environment of the school on teaching learning and education outcomes. Milwaukee, Centre for Architecture and Urban Planning Research.

[35]. Maduewesi, E.J. (2005a). Early childhood care in Nigeria. In E.J. Maduewesi (Ed), Benchmarks and Global Trends in Education, Enugu: Cily Sylva Influence Enterprises

[36]. Marcon, R.A. (2002). Moving up the grades: Relationship between preschool model and later school success, Early Childhood Research and Practice, 4(1), 37-59.

[37]. Minet, P.M. (2000). Chilcare and development. London: JMurray Publishers Ltd.

[38]. Mitchell, T.T. (1990). Human growth and development: The childhood years. Calgary; Alberta: Detselig Enterprises.

[39]. Moore, d. (1998). Improve your schools' atmosphere. School Planning and Management, 37(10): 18

[40]. Moronkola, O. A., Akinsola, M. K., \& Abe, C. V. (2000). The nature of curriculum. Ibadan: Royal People (Nigeria) Ltd.

[41]. Obadiah, S.A. (2008). Early childhood education in the $21^{\text {st }}$ century: The use of toys and other stimulation materials. Knowledge Review: A Multidisciplinary Journal of NAFAK, 17(5), 107-111

[42]. O'Connor, T.G. \& Scott, S.B.C. (2007). Parenting and outcomes for children. NY: Joseph Rowntree Foundation.

[43]. Ojameruaye, E. (2010). Promoting Early Childhood Care and Education in Urhobol and, Nigeria: The Role of Private Voluntary Organisations. Scottsdale, Arizona State, U.S.A: International Foundation for education \& Self-help (IFESH).

[44]. Okoro, D.C.U. (2004). Universal Basic Education. In E.A. Yoloye \& A.O. Osiyale (Ed) Burning Issues in Nigerian Education. Ibadan: Wemilore Press.

[45]. Okorodudu, R. E. (1995). Deviant behaviours in schools. In V. F. Peretomode (Ed). Sociology of Education. Lagos: Obaroh \& Ogbinake Publishers Ltd.

[46]. Olson, H.C. (2000). Fetal alcohol syndrome. In A Kazdin (Ed.), Encyclopedia of Psychology. New York: American Psychological Association and Oxford University.

[47]. Olson, H.C., \& Burgess, D.M. (1996). Early intervention with children prenatally exposed to alcohol and other drugs. In M. J. Guralnick (Eds.). The effectiveness of early intervention. Bathmore: Paul H. Brookes.

[48]. Reynold, A.J., Maverogenes, N. A., Bezruczko, N., \& Hagemann, M. (1996). Cognitive and family support mediators of preschool effectiveness: A confirmatory analysis. Child development, 67(3), 1119-1140

[49]. Rolnick, A., \& Gruncward, R. (2003). Early childhood development: Economic development with a high public return. Fedgazette

[50]. Shekwoyandu, D. (2014). Teachers' perception of the academic performance and behaviours of children of divorced parents to school work in junior secondary schools. An unpublished PGDE thesis. University of Maiduguri. 
The Influence of Prenatal, Home and Environmental Factors on Learning Outcomes of Pre-...

[51]. Sherman, J., \& Ellen, M. (2007). Developing a nutrition and health education program for primary schools in zambia. Journal of Nutrition, Education and Behavior, 39, 335-342.

[52]. Stipek, D., Feiler, R., Daniels, D., \& Milburn, S. (1995). Effects of different instructional approaches on young children's achievement and motivation. Child Development, 66(1), 209-223.

[53]. Tambowua, S. (2013). Early childhood education: Issues and problems. Journal of Education and Social Research, 3(5), 173-179

[54]. Willcutt, E.G., Pennington, B,F., Boada, R., Ogline, J.S., Tunick R.A., Chhabidas, N.A., \& Olson, R.K. (2001). A comparison of the cognitive deficits in reading disability and attention-deficit hyperactivity disorder. Journal of Abnormal Psychology, 110, 157172 . 